Jurnal Scripta Teologi dan Pelayanan Kontekstual
ISSN 2685-2144 (Print)
ISSN 2722-8231 (Online)
Http://ejournal.stte.ac.id
Vo. 10, No. 2, 21-36, 2020

\title{
Kepemimpnan Wanita Dalam Gereja
} Rotua Marlina Manalu

Dosen STT Misia, linamanalu18@gmail.com

\begin{tabular}{l} 
INFO ARTIKEL \\
\hline Sejarah Artikel: \\
Diterima : 20-10 2020 \\
Direvisi : 19-11-2020 \\
Disetujui: 19-1 1-2020 \\
Dipublikasi: 28-11- \\
2020 \\
\hline Kata Kunci: \\
Kepemimpinan, Wanita, \\
Gereja \\
\end{tabular}

$-$

Keywords: Leadership, Women, Church

\begin{abstract}
Abstrak
Pemimpin dan kepemimpinan tidak dapat dipisahkan satu dengan yang lainnya. Apabila menyinggung tentang kepemimpinan, hal itu berkaitan dengan mendiskusikan suatu proses. Tetapi berbicara tentang pemimpin Kristen berarti berbicara tentang individu atau pribadi yang dipanggil oleh Tuhan untuk melaksanakan tugas kepemimpinan. Dewasa ini kepemimpinan dalam berbagai bidang telah diwarnai oleh terlibatnya wanita dalam memberikan peran sertanya dalam upaya meningkatkan pembangunan bangsa. Termasuk juga dalam kepemimpinan di gereja. Artikel ini akan memaparkan secara singkat tentang gambaran kepemimpinan wanita dalam gereja
\end{abstract}

\begin{abstract}
Leaders and leadership can not be separated from one another. If we mention the leadership, it relates to discuss the process. But talking about the Christian's leader is talking about private individuals or who are called by God to carry out the task of leadership. Today leadership in various fields has been characterized by the involvement of women in delivering participation in efforts to improve the development of the nation. Included the leadership in the church. This article will explain briefly about the image of women in church of leadership
\end{abstract}

\section{PENDAHULUAN}

Berbicara tentang perempuan haruslah dimulai dengan menempatkan mereka, pertama-tama sebagai manusia. Pada dasarnya perempuan dan laki-laki sama cerdas otaknya, sama mulia budinya, dan sama luhur cita-citanya. ${ }^{1}$ Mereka juga sama- sama memiliki impian dan harapan. Juga sama-sama didera oleh kekhawatiran dan ketakuan. Keduanya mempunyai beban alamiah untuk memenuhi kebutuhan dasar sebagai mahluk hidup. Sama-sama butuh makan dan minum, tidur dan pergaulan, cinta dan penghargaan. Mereka tentu memiliki

\footnotetext{
${ }^{1}$ Toety Heraty Noehardi, Perempuan Indonesia (Jakarta: CV. Tomassu, 1991).13
} 
potensi untuk memimpin, termasuk aktuaisasi potensi kepemimpinan sebagai individu dan sebagai mahluk sosial. ${ }^{2}$

Menghitung jumlah pemimpin yang berjenis kelamin perempuan dalam berbagai bidang kehidupan, saat ini telah lahir banyak pemimpin-pemimpin handal dari kaum perempuan. Dalam sejarah pemimpin perempuan di bidang politik dapat dihitung dengan jari. Filsuf, penulis, ahli matematik, penemu kawakan, hampir semuanya laki-laki. Catatan sejarah ini bisa membuat orang berasumsi bahwa peran kepemimpinan perempuan dalam semua bidang dan taraf kehidupan memang amatlah kecil. Perempuan memegang peran bayangan di balik layar.

Gambaran menarik dapat dilihat akhir-akhir ini dengan munculnya namanama perempuan dalam sejarah kehidupan kontemporer. Dalam bidang politik, ditemui nama-nama seperti Cory Aquino, Golda Meir, Margaret Thatcher. Dalam bidang sains ada Mari Curie, Pratiwi Sudarmono. Antara penulis kenamaan muncul beberapa nama di antaranya Patricia Aburdene, La Rose dan masih banyak lagi yang lain. Dalam bidang gerejawi, beberapa waktu yang lalu tepatnya pada tanggal 11-17 November 2014, telah terpilih dan didaulat sebagai ketua umum PGI seorang wanita dengan segudang prestasinya yaitu Pdt. Dr. Henriette Tabita Lebang, M.Th. ${ }^{3}$ dengan demikian kepemimpinan menurut perspektif wanita dimungkinkan.

Mengomentari pokok seputar kepemimpinan, James MacGregor dalam bukunya yang dikutip oleh Yakob Tomatala mengatakan bahwa kepemimpinan adalah salah satu fenomena yang paling banyak diamati dan paling sedikit dipahami di dunia ini. ${ }^{4}$

Meninjau apa yang dikatakan oleh Burns, patutlah ditanyakan tentang alasan mendasar apa yang menyebabkan pernyataan dimaksud disampaikan. Ada beberapa alasan yang dikemukakan antara lain: Pertama, kepemimpinan adalah suatu seni yang usianya setua umur manusia di bumi, di mana orang telah mempraktekkannya dalam kurun waktu yang cukup panjang. Kedua, kepemimpinan adalah suatu gejala universal di mana kepemimpinan selalu ada pada setiap budaya dari segala bangsa di seluruh dunia. ${ }^{5}$ Ketiga, kepemimpinan adalah suatu pokok yang kompleks yang telah dipelajari untuk jangka waktu yang panjang tetapi baru saja berkembang menjadi satu ilmu multi-disiplin dalam kurun waktu yang tidak lebih dari satu setengah abad belakangan ini. Keempat, kepemimpinan bukan saja suatu ilmu sosial yang lugas/terbuka, tetapi suatu seni yang dapat mencipta keharmonisan ataupun kesenjangan di antara teori dan praktek; apa yang dipikirkan dan apa yang dipraktekkan; satu dan beragam; serta idealisme yang benar dan realitas yang nyata, dan faktor-faktor yang terkait lainnya. ${ }^{6}$ Karena itu kepemimpinan dapat dilihat dari banyak sudut yang berbeda.

Di satu sisi, pemimpin adalah orang yang memiliki pengikut, di mana para pengikut tersebut memiliki sejumlah kepentingan pribadi atau karena struktur organisasi, tetapi pengikut mutlak harus ada. Di sisi lain, kepemimpinan adalah suatu tindakan. Para pemimpin dikenal melalui tindakan yang mereka perlihatkan.

\footnotetext{
${ }^{2}$ Noehardi.13

3 Bahana (Majalah), Edisi Februari 2015, Vol. 286, 8

${ }^{4}$ Yakob Tomatala, Kepemimpinan Kristen (Jakarta: YT. Leadership Faundation, 2005).1

${ }^{5}$ Y. Tomatala, Kepemimpinan Yang Dinamis (Jakarta: YT. Leadership Foundation, 1998).1-2

6 Tomatala. 2
} 

berikut:

Dr. J. Robert Clinton membuat suatu rumusan tentang kepemimpinan sebagai

"Leadership is a dynamic process over an extended period of time in various situations in which a leader utilizing leadership resources, and by specific leadership behavior, influences the thoughts and activity of followes, toward accomplishment of person/task aims mutually beneficial for leaders, followers, and the macro context of which they are a part" 7 .

Rumusan di atas menunjukkan betapa terikatnya ilmu kepemimpinan dengan si pemimpin itu sendiri dan seperti mata uang yang mempunyai dua sisi.

Kepemimpinan Kristen adalah kepemimpinan yang dimotivasi oleh kasih dan disediakan khusus untuk melayani. Para pemimpin Kristen yang terbaik memperlihatkan sifat-sifat yang penuh dedikasi tanpa pamrih dimungkinkan karena orang Kristen tahu bahwa Allah mempunyai strategi besar di mana ia menjadi bagiannya, keberanian diperbesar oleh kekuatan yang datang dari Roh yang berdiam di dalam hati kita, ketegasan datang karena mengetahui bahwa tanggung jawab tidak terletak pada dirinya, belas kasihan/ kerendahan hati berasal dari kesadaran bahwa Allah-lah yang melakukan pekerjaan tersebut, dan kepandaian persuasive didasarkan pada kesetiaan kepada suatu alasan yang melampaui segala alasan lainnya yang menjadi ciri pemimpin agung. ${ }^{8}$

Senada dengan hal tersebut di atas, Robert Clinton menjelaskan dalam bukunya tentang siapakah pemimpin Kristen itu.

"A leader, in the Biblical context for which we are interested in studying leadership selection and training, is a person, -1) With God-given capacity AND -2) with God-given responsibility to INFLUENCE -3) a specific group of God's people -4) Toward God's purposes for the group. ${ }^{9}$

Rumusan di atas diaplikasikan dengan tokoh-tokoh dalam Alkitab dalam Perjanjian Baru, seperti para rasul dan hamba-hamba Tuhan yang setia melayani dalam sejarah gereja.

Bila melihat kepada zaman sekarang ini, terjadi perubahan yang cukup signifikan tentang bagaimana masyarakat secara umum memandang wanita. Wanita di mana-mana memang masih sering menjadi pihak yang tertindas (hal ini memang salah satu konsekuensi dosa), namun tidak separah zaman dahulu. Setidaknya perbedaan paling mencolok antara zaman bapa gereja dengan zaman sekarang adalah bahwa pada zaman dahulu wanita hampir tidak memiliki kesempatan untuk mengemban pendidikan yang cukup. Bisa dikatakan bahwa hal ini adalah 'lingkaran setan', karena di satu sisi sistem budaya masyarakat tidak mengizinkan wanita mendapatkan pendidikan yang memadai, akhirnya karena tidak berpendidikan, wanita semakin tersubordinasi, ibarat kata: 'tidak bisa apaapa kecuali mengurus urusan rumah tangga'. Hal ini sudah tidak lagi terjadi pada zaman sekarang khususnya di masyarakat kota metropolitan yang modern (dan dalam negara demokrasi tentunya). Zaman sekarang status wanita sudah sangat egaliter dengan pria, dengan memiliki kesempatan yang setara. Berkat munculnya

\footnotetext{
${ }^{7}$ Edgar J Elliston, Basic Leadership Defitnitions in the Introduction to Leadership Theory, ed. Robert J Clinton (Pasadena: Fuller Theological Seminary, 1988).2

${ }^{8}$ Pamudji S, Kepemimpinan Pemerintahan Di Indonesia (Jakarta: PT. Bina Aksara, 1986).5

${ }^{9}$ S.3
} 
aliran feminisme yang sudah gerah dengan penindasan dari pria atas wanita dan ketidakadilan yang diterima wanita, kesetaraan itu mulai terwujud dalam banyak ranah. Namun semangat feminisme dan kesetaraan gender ini telah kebablasan ketika akhirnya wanita berlomba-lomba untuk menggapai cita-cita dan ambisinya setinggi langit dalam hal karier maupun pendidikan, dan di sisi lain mengabaikan peran kodratinya sebagai seorang wanita. Tentu bukanlah hal yang salah untuk mengemban pendidikan dan menjajaki dunia karier, akan tetapi fenomena yang sekarang ini mulai marak adalah wanita semakin menganggap bahwa perannya sebagai penolong yang sepadan, sebagai mahluk yang caring and nurturing ini menjadi tidak relevan lagi.

\section{KONTROVERSI TENTANG PELAYANAN WANITA}

Tiga pemahaman tentang pelayanan wanita dalam gereja. Ada tiga sudut pandang utama, di antaranya:

\section{Sebuah pelayanan yang identik dengan wanita}

Many believe that there are no biblical reasons (or any other reasons) why a woman should not, if she has the necessary gifts and calling, exercise the same kinds of ministry in the church as does a man. Those who hold this view are in favour of woman taking part in the local church and in the denominational structures in all respects as men do, including being ordained and having the churches and parishes. ${ }^{10}$

Alkitab tidak mencatat tentang keberatannya untuk menjelaskan kesetaraan serta kesempatan dari masing-masing laki-laki dan perempuan. Baik laki-laki maupun wanita, semuanya diberdayakan oleh Allah untuk melakukan apa yang menjadi tugas dan tanggung jawabnya dalam memenuhi kehendak-Nya di muka bumi ini.

\section{Tidak ada pelayanan untuk wanita}

Pemahaman lain, ada banyak orang yang percaya bahwa Allah telah memanggil perempuan hanya sebagai peran pendukung, sebagai pembantu kepada manusia dalam pelayanannya. Pada pandangan ini, perempuan tidak dipanggil Allah untuk terlibat dalam pelayanan di gereja, dalam melakukan ibadah, sakramen, khotbah, dan memimpin dalam doa di depan jemaat. Perempuan hanya hanya sebagai peran bayangan di belakang layar. ${ }^{11}$

Dalam bukunya, Mercy Oduyoye menjelaskan bahwa ada tiga hal yang telah diusulkan oleh DGD (dewan gereja se dunia) untuk diperhatikan oleh gereja-gereja anggotanya, yaitu: Pertama, partisipasi penuh dari kaum perempuan dalam kehidupan bergereja dan bermasyarakat. Kedua, pandangan dan komitmen kaum perempuan terhadap masalah-masalah keadilan, perdamaian dan keutuhan cipataan. Ketiga, perempaun dan pemberlakuan teologi (doing theology), serta saling berbagi spiritualitas. ${ }^{12}$

Dari uraian di atas, jelaslah bahwa gereja-gereja semakin ditantang untuk mengakui sumbangan-sumbangan dari kaum perempuan. Diharapkan bahwa kaum wanita diberikan tempat yang sejajar dengan kaum laki-laki dalam semua hal

\footnotetext{
${ }^{10}$ Ward Powers, The Ministry of Women in the Church (Australia: Southwood Press, 1996).15

11 Powers. 15

${ }^{12}$ Mercy Oduyeye, Siapa Yang Akan Menggulingkan Batu Itu? (Jakarta: BPK Gunung Mulia, 1995).10
} 
yang dilakukan gereja sehingga gereja bias terbuka terhadap cara-cara pendekatan baru dalam hidup dan misinya.

\section{Persamaan dan Perbedaan dalam Pelayanan}

Ada banyak pandangan Kristen yang memegang pemahaman lain, di antaranya para wanita hanya memungkinkan melakukan pelayanan sampai batas tertentu saja di gereja, selebihnya diambil alih oleh laki-laki.

Alkitab tidak pernah meniadakan perbedaan antara pria dan wanita. Mereka sama dalam beberapa hal, tetapi mereka juga berbeda dalam banyak hal lain. Dalam kedaulatan-Nya yang mutlak, Allah telah menetapkan laki-laki di atas wanita dalam hal otoritas, terutama dalam gereja dan rumah tangga. Penetapan otoritas ini tidak berarti menghilangkan peranan dan optimalisasi talenta wanita. Allah perlu menetapkan urutan otoritas dalam segala hal, karena kalau tidak ada aturan yang jelas, manusia akan memakai patokan yang justru lebih mengacaukan tatanan masyarakat.

Wanita tetap diberi ruang gerak tertentu dalam gereja. Mereka dipakai Allah untuk bernubuat atau terlibat dalam pekerjaan Tuhan yang lain. Eksistensi beberapa wanita Kristen di dalam Perjanjian Baru menunjukkan keistimewaan peranan mereka dalam Pekabaran Injil. Wanita juga ada kemungkinan boleh mengajar, asalkan hal itu tidak didasari pada konsep atau motivasi ingin mendominasi laki-laki.

\section{KESETARAAN WANITA DAN PRIA DALAM ALKITAB}

Sudah banyak diketahui bahwa jumlah wanita melebihi setengah jumlah anggota jemaat Tuhan Yesus, maka kita perlu memahami peran yang diperintahkan Allah bagi tubuh Kristus. Di sebagian besar gereja dan pelayanan, wanita dipandang sebagai pekerja yang berharga, karena mereka sering melakukan sebagian besar tugas pelayanan. Namun tidak semua orang setuju dengan peranan wanita. Wanita sering dibatasi untuk bidang-bidang tertentu dalam pelayanan di gereja yang terkait dengan berbicara dan memimpin. Beberapa gereja membolehkan pendeta wanita, tetapi banyak gereja tidak membolehkan pendeta wanita. Sebagian gereja membolehkan wanita untuk mengajar selagi gereja-gereja lain tidak membolehkan. Sebagian membatasi wanita agar tidak berbicara sama sekali selama ibadah gereja.

Ungkapan Alkitab tentang wanita dari bagian-bagian awalnya. Wanita, seperti halnya pria, diciptakan dalam gambar Allah. "Maka Allah menciptakan manusia itu menurut gambar-Nya, menurut gambar Allah diciptakan-Nya dia; laki-laki dan perempuan diciptakan-Nya mereka”. (Kejadian 1:27).

Alkitab menjelaskan bahwa Allah menciptakan Adam sebelum la menciptakan Hawa, dan ini memang fakta yang berarti secara rohani (Timotius 2:3). Hal tersebut tidak membuktikan keunggulan pria atas wanita. Kita tahu bahwa Allah menciptakan hewan sebelum manusia (Kejadian 1:24-28), dan tak seorangpun berpendapat bahwa hewan lebih unggul dari manusia. ${ }^{13}$ Istri diciptakan sebagai penolong suaminya (lihat Kejadian 2:18). Hal ini juga tidak membuktikan kedudukan lebih rendah dari istri, tetapi hanya mengungkapkan peran istri dalam

${ }^{13}$ Harus juga dicatat bahwa setiap manusia sejak Adam diciptakan oleh Allah setelah Allah menciptakan wanita yang melahirkannya. Setiap pria sejak Adam berasal dari seorang wanita, sebagaimana kita diingatkan oleh Paulus dalam 1 Korintus 11:11-12. Tentunya tak seorangpun berpendapat bahwa perintah ilahi ini membuktikan bahwa pria lebih rendah dari ibunya. 
pernikahan. Roh Kudus diberikan sebagai penolong kita, tetapi kedudukan-Nya tentu tidak di bawah kita. Sebaliknya, Roh Kudus ada di atas kita. Dapat dikatakan bahwa penciptaan wanita oleh Allah sebagai penolong suaminya membuktikan bahwa pria butuh pertolongan. Allahlah yang berkata bahwa tidak baik bagi pria hidup sendiri (Kejadian2:18). Kebenaran itu telah banyak kali dibuktikan dalam sejarah ketika pria ditinggalkan tanpa istri yang membantunya.

Kitab Kejadian menjelaskan bahwa wanita pertama diciptakan dari daging manusia pertama. Wanita diambil dari pria, dengan menunjuk pada fakta bahwa pria kehilangan sesuatu tanpa kehadiran wanita, dan keduanya awalnya adalah satu. Tambahan pula, apa yang dipisahkan Allah dimaksudkan-Nya untuk disatukan lagi melalui hubungan seks, sebagai cara untuk beranak-cucu, dan juga ungkapan kasih dan menikmati kesenangan bersama di mana keduanya saling bergantung.

Segala sesuatu tentang pelajaran dari penciptaan bertentangan dengan pendapat tentang satu jenis kelamin sebagai lebih di atas dari jenis kelamin lain, atau satu jenis kelamin berhak mendominasi jenis kelamin lain. Dan hanya karena Allah telah menentukan peranan yang berbeda untuk wanita dalam pernikahan atau pelayanan tidaklah berkaitan dengan kesamaan wanita dengan pria dalam Kristus, di dalam mana "tidak ada perbedaan laki-laki atau wanita" (Galatia 3:28). Di bawah ini ada beberapa hal dalam Alkitab tentang laki-laki dan wanita:

\section{(1) Laki-laki dan perempuan sama-sama diciptakan menurut gambar dan rupa Allah}

"Maka Allah menciptakan manusia itu menurut gambar-Nya, menurut gambar Allah diciptakan-Nya dia; laki-laki dan perempuan diciptakan-Nya mereka" (Kejadian 1:27). "Jawab Yesus: "Tidakkah kamu baca, bahwa la yang menciptakan manusia sejak semula menjadikan mereka laki-laki dan perempuan?" (Matius 19:4). "Sebab pada awal dunia, Allah menjadikan mereka laki-laki dan perempuan," (Markus 10:6).

\section{(2) Allah memberkati laki-laki dan perempuan}

"Laki-laki dan perempuan diciptakan-Nya mereka. Ia memberkati mereka dan memberikan nama "Manusia" kepada mereka, pada waktu mereka diciptakan” (Kejadian 5:2).

\section{(3) Perempuan juga dipanggil sebagai nabi}

"Lalu Miryam, nabiah itu, saudara perempuan Harun, mengambil rebana di tangannya, dan tampillah semua perempuan mengikutinya memukul rebana serta menari-nari" (Keluaran 15:20). "Pada waktu itu Debora, seorang nabiah, isteri Lapidot, memerintah sebagai hakim atas orang Israel" (Hakim-hakim 4:4). "Maka pergilah imam Hilkia, Ahikam, Akhbor, Safan dan Asaya kepada nabiah Hulda, isteri seorang yang mengurus pakaian-pakaian, yaitu Salum bin Tikwa bin Harhas; nabiah itu tinggal di Yerusalem, di perkampungan baru. Mereka memberitakan semuanya kepadanya" (2 Raja-raja 22:14). "Maka pergilah Hilkia dengan orang-orang yang disuruh raja kepada nabiah Hulda, isteri seorang yang mengurus pakaian-pakaian, yaitu Salum bin Tokhat bin Hasra, penunggu pakaian-pakaian; nabiah itu tinggal di Yerusalem, di perkampungan baru. Mereka berbicara kepadanya sebagaimana yang diperintahkan" (2 Tawarikh 24:22). "Ya Allahku, ingatlah bagaimana Tobia dan Sanbalat masing-masing telah bertindak! Pun tindakan nabiah Noaja dan nabinabi yang lain yang mau menakut-nakutkan aku" (Nehemia 6:14). "Kemuliaan bagi 
Allah di tempat yang mahatinggi dan damai sejahtera di bumi di antara manusia yang berkenan kepada-Nya" (Lukas 2:14).

\section{(4) Perempuan juga bernubuat dan dipenuhi Roh Kudus}

"Juga ke atas hamba-hamba-Ku laki-laki dan perempuan akan Kucurahkan Roh-Ku pada hari-hari itu dan mereka akan bernubuat" (Kisah 2:18). "Sebab kepada yang seorang Roh memberikan karunia untuk berkata-kata dengan hikmat, dan kepada yang lain Roh yang sama memberikan karunia berkata-kata dengan pengetahuan. Kepada yang seorang Roh yang sama memberikan iman, dan kepada yang lain la memberikan karunia untuk menyembuhkan. Kepada yang seorang Roh memberikan kuasa untuk mengadakan mujizat, dan kepada yang lain la memberikan karunia untuk bernubuat, dan kepada yang lain lagi la memberikan karunia untuk membedakan bermacam-macam roh. Kepada yang seorang la memberikan karunia untuk berkata-kata dengan bahasa roh, dan kepada yang lain Ia memberikan karunia untuk menafsirkan bahasa roh itu. Tetapi semuanya ini dikerjakan oleh Roh yang satu dan yang sama, yang memberikan karunia kepada tiap-tiap orang secara khusus, seperti yang dikehendaki-Nya" (1 Korintus 12:811).

\section{(5) Laki-laki dan perempuan sama-sama memberikan persembahan}

"Maka datanglah mereka, baik laki-laki maupun perempuan, setiap orang yang terdorong hatinya, dengan membawa anting-anting hidung, anting-anting telinga, cincin meterai dan kerongsang, segala macam barang emas; demikian juga setiap orang yang mempersembahkan persembahan unjukan dari emas bagi TUHAN" (Keluaran 35:22). "Semua laki-laki dan perempuan, yang terdorong hatinya akan membawa sesuatu untuk segala pekerjaan yang diperintahkan TUHAN dengan perantaraan Musa untuk dilakukan-mereka itu, yakni orang Israel, membawanya sebagai pemberian sukarela bagi TUHAN" (Keluaran 35:29).

\section{(6) Perempuan menyanyi di hadapan Tuhan}

"Tetapi pada waktu mereka pulang, ketika Daud kembali sesudah mengalahkan orang Filistin itu, keluarlah orang-orang perempuan dari segala kota Israel menyongsong raja Saul sambil menyanyi dan menari-nari dengan memukul rebana, dengan bersukaria dan dengan membunyikan gerincing" (1 Samuel 18:6). "Yeremia membuat suatu syair ratapan mengenai Yosia. Dan sampai sekarang ini semua penyanyi laki-laki dan penyanyi perempuan menyanyikan syair-syair ratapan mengenai Yosia, dan mereka jadikan itu suatu kebiasaan di Israel. Semuanya itu tertulis dalam Syair-syair Ratapan" (2 Tawarikh 35:25). "Selain dari budak mereka laki-laki dan perempuan yang berjumlah tujuh ribu tiga ratus tiga puluh tujuh orang. Pada mereka ada dua ratus penyanyi laki-laki dan perempuan" (Ezra 2:65). "Selain dari budak mereka laki-laki dan perempuan yang berjumlah tujuh ribu tiga ratus tiga puluh tujuh orang. Pada mereka ada dua ratus empat puluh lima penyanyi laki-laki dan perempuan" (Nehemia 7:76). "Pada hari itu mereka mempersembahkan korban yang besar. Mereka bersukaria karena Allah memberi mereka kesukaan yang besar. Juga segala perempuan dan anak-anak bersukaria, sehingga kesukaan Yerusalem terdengar sampai jauh" (Nehemia 12:43). 
(7) Laki-laki dan perempuan sama-sama bisa mengerti hukum Taurat

"Lalu pada hari pertama bulan yang ketujuh itu imam Ezra membawa kitab Taurat itu ke hadapan jemaah, yakni baik laki-laki maupun perempuan dan setiap orang yang dapat mendengar dan mengerti" (Nehemia 8:2).

(8) Perempuan melakukan perbuatan baik

"Banyak wanita telah berbuat baik, tetapi kau melebihi mereka semua" (Amsal $31: 29)$.

(9) Perempuan bisa memiliki iman yang hebat

"Maka Yesus menjawab dan berkata kepadanya: "Hai ibu, besar imanmu, maka jadilah kepadamu seperti yang kaukehendaki." Dan seketika itu juga anaknya sembuh" (Matius 15:28).

(10) Perempuan sebagai penyembah yang hebat

"Tetapi Yesus mengetahui pikiran mereka lalu berkata: "Mengapa kamu menyusahkan perempuan ini? Sebab ia telah melakukan suatu perbuatan yang baik pada-Ku" (Matius 26:10). "Ketika Yesus berada di Betania, di rumah Simon si kusta, dan sedang duduk makan, datanglah seorang perempuan membawa suatu buli-buli pualam berisi minyak narwastu murni yang mahal harganya. Setelah dipecahkannya leher buli-buli itu, dicurahkannya minyak itu ke atas kepala Yesus" (Markus 14:3).

(11) Perempuan sebagai pengajar bagi para perempuan dan anak-anak "Maka dengarlah firman TUHAN, hai perempuan-perempuan, biarlah telingamu menerima firman dari mulut-Nya; ajarkanlah ratapan kepada anak-anakmu perempuan, dan oleh setiap perempuan nyanyian ratapan kepada temannya" (Yeremia 9:20). "Dan dengan demikian mendidik perempuanperempuan muda mengasihi suami dan anak-anaknya" (Titus 2:4). "Demikian juga perempuan-perempuan yang tua, hendaklah mereka hidup sebagai orang-orang beribadah, jangan memfitnah, jangan menjadi hamba anggur, tetapi cakap mengajarkan hal-hal yang baik" (Titus 2:3).

(12) Laki-laki dan perempuan sama-sama dipenuhi Roh Kudus

"Juga ke atas hamba-hambamu laki-laki dan perempuan akan Kucurahkan Roh-Ku pada hari-hari itu" (Yoel 2:29).

(13) Perempuan sebagai pendukung/pelayan dalam pelayanan Kristus

"Dan ada di situ banyak perempuan yang melihat dari jauh, yaitu perempuanperempuan yang mengikuti Yesus dari Galilea untuk melayani Dia” (Matius 27:55). "Mereka semuanya telah mengikut Yesus dan melayani-Nya waktu la di Galilea. Dan ada juga di situ banyak perempuan lain yang telah datang ke Yerusalem bersama-sama dengan Yesus" (Markus 15:41). "Yohana isteri Khuza bendahara Herodes, Susana dan banyak perempuan lain. Perempuan-perempuan ini melayani rombongan itu dengan kekayaan mereka" (Lukas 8:3).

(14) Perempuan, orang pertama yang melihat Kristus bangkit

"Mereka segera pergi dari kubur itu, dengan takut dan dengan sukacita yang besar dan berlari cepat-cepat untuk memberitahukannya kepada murid-murid Yesus" (Matius 28:8). "Mereka sangat ketakutan dan menundukkan kepala, tetapi kedua orang itu berkata kepada mereka: "Mengapa kamu mencari Dia yang hidup, di antara orang mati?" (Lukas 24:5). 
(15) Perempuan dan laki-laki berdoa bersama-sama

"Mereka semua bertekun dengan sehati dalam doa bersama-sama, dengan beberapa perempuan serta Maria, ibu Yesus, dan dengan saudara-saudara Yesus" (Kisah 1:14).

(16) Laki-laki dan perempuan sama-sama dibaptis dengan air "Tetapi sekarang mereka percaya kepada Filipus yang memberitakan Injil tentang Kerajaan Allah dan tentang nama Yesus Kristus, dan mereka memberi diri mereka dibaptis, baik laki-laki maupun perempuan” (Kisah 8:12).

(17) Laki-laki dan perempuan menjadi pelayan Paulus

"Allah yang telah menjadikan bumi dan segala isinya, la, yang adalah Tuhan atas langit dan bumi, tidak diam dalam kuil-kuil buatan tangan manusia” (Kisah 17:34).

(18) Para perempuan beriman sangat menonjol dalam gereja

"Beberapa orang dari mereka menjadi yakin dan menggabungkan diri dengan Paulus dan Silas dan juga sejumlah besar orang Yunani yang takut kepada Allah, dan tidak sedikit perempuan-perempuan terkemuka" (Kisah 17:4).

(19) Para perempuan bekerja keras untuk Tuhan

"Salam kepada Trifena dan Trifosa, yang bekerja membanting tulang dalam pelayanan Tuhan. Salam kepada Persis, yang kukasihi, yang telah bekerja membanting tulang dalam pelayanan Tuhan" (Roma 16:12).

(20) Laki-laki dan perempuan sama-sama memiliki keselamatan dalam Kristus "Dalam hal ini tidak ada orang Yahudi atau orang Yunani, tidak ada hamba atau orang merdeka, tidak ada laki-laki atau perempuan, karena kamu semua adalah satu di dalam Kristus Yesus" (Galatia 3:28).

Ayat-ayat di atas memberikan penjelasan aspek-aspek kesetaraan laki-laki dan perempuan seperti dalam keselamatan, berkat, kepenuhan Roh Kudus dan pelayanan. Ayat-ayat di atas juga menjelaskan bahwa laki-laki dan perempuan diciptakan berbeda secara biologis dan seksual, namun memiliki atribut dan kekuatan Ilahi yang sama. ${ }^{14}$ Masih banyak lagi yang bisa digali dari Alkitab tentang kesetaraan ini.

\section{WOMEN IN MINISTRY IN THE OLD TESTAMENT}

Dengan peletakan dasar ini, dapat diperhatikan para wanita yang dipakai Allah untuk menggenapi tujuan ilahi-Nya dalam Perjanjian Lama. Sudah jelas, Allah memanggil pria dalam pelayanan jabatan selama masa Perjanjian Lama, seperti yang dilakukan-Nya selama masa Perjanjian Baru. Kisah-kisah pria, seperti Musa, Harun, Yosua, Yusuf, Samuel dan Daud, mengisi halaman-halaman Perjanjian Lama. Tetapi banyak wanita tampil sebagai bukti bahwa Allah dapat memanggil dan memakai siapapun yang la inginkan, dan para wanita yang diperlengkapi oleh Allah cukup untuk tugas sesuai panggilanNya.

Sebelum membahas wanita secara khusus, harus dicatat bahwa setiap orang pilihan Allah dalam Perjanjian Lama lahir dari seorang wanita. Pasti tidak akan ada Musa tanpa wanita bernama Yokebed (Keluaran 6:20). Tidak akan ada juga orangorang pilihan Allah jika bukan karena ibu mereka. Kepada wanita Allah telah memberi tanggung-jawab berat dan pelayanan yang patut dipuji untuk mendidik

\footnotetext{
${ }^{14}$ Jeane Becher, Perempuan, Agama Dan Seksualitas (Jakarta: BPK Gunung Mulia, 2004).7
} 
anak-anak dalam Tuhan (2 Timotius 1:5). Yokebed bukan hanya ibu dari dua pria yang dipanggil Allah, yakni Musa dan Harun, tetapi juga ibu dari seorang wanita yang dipanggil Allah, saudara perempuan dari Musa dan Harun, seorang nabiah dan pemimpin pujian bernama Miriam (lihat Keluaran 15:20). Dalam Mika 6:4, Allah mengkategorikan Miriam, sama dengan Musa dan Harun, sebagai salah seorang pemimpin Israel.

Alkitab memperlihatkan bahwa wanita memiliki peran dalam kepemimpinan yang sama dengan laki-laki. Perjanjian Lama megungkapkan beberapa tokoh perempuan yang berperan sebagai pemimpin. ${ }^{15}$

\section{WOMEN IN MINISTRY IN THE NEW TESTAMENT}

Selama hidup, Yesus telah memperlihatkan sikap terbuka teradap kaum wanita yang diciptakan serupa dengan gambar Allah, sama seperti kaum laki-laki. Rasul Paulus menangkap sikap Yesus yang terbuka dalam Galatia 3:28. ${ }^{16}$ Dalam suratnya Paulus menyebutkan kaum perempuan sebagai rekan kerja Paulus yang asli memberitakan juga gelar-gelar misionaris kepada kaum perempuan seperti rekan sekerja (Priskila, Kis. 16:3), diakonos (Febe, Roma 16:1), dan rasul, (Yunia, Roma 16:7). Paulus juga mengakui kesederajatan kaum yang bekerja bersamanya seperti Euodia dan Sintikhe yang telah berjuang bersamanya (Fil. 4:2-3). ${ }^{17}$

Sikap Tuhan Yesus juga tercermin dalam pemberian tempat terhadap perempuan. Salah satu contohnya ketika Dia berbicara dengan perempuan Samaria (Yoh. 4), mengajar perempuan (seperti melayani di rumah Marta dan Maria), Tuhan Yesus juga memperlihatkan betapa pentingnya pemberian janda miskin (Luk. 21:1-4). Dengan cara yang sama, Tuhan Yesus memberikan anugerah khusus kepada perempuan yang menjamah jubah-Nya, dan Dia pun memuji imannya (Mat. 9:20-22). Setelah kebangkitan-Nya, Tuhan menampakkan diri pertama sekali kepada perempuan, sehingga mereka berani memberitakan Kabar Baik kepada para rasul (Mat. 28:8-18; Yoh. 20:4-16).

Hal menarik juga didapati ketika seorang wanita yang dipanggil oleh Allah sebagai nabiah dalam Perjanjian Baru. Ketika Yesus baru berusia beberapa hari, Hana mengakuni-Nya dan mulai memberitakan tentang kedudukan-Nya sebagai Mesias. ${ }^{18}$ Perlu dicatat bahwa Hana membicarakan tentang Yesus kepada semua orang "yang mencari pengampunan Yerusalem" sudah tentu termasuk juga lakilaki. Jadi Hana dikatakan telah mengajar tentang Kristus kepada kaum pria.

Dengan landasan ini, maka kedudukan laki-laki dan perempuan adalah sama di mata Tuhan, karena itu baik laki-laki maupun perempuan mempunyai kesempatan yang sama untuk melayani termasuk di dalam gereja. Dan perempuan pun mempunyai peran dalam kepemimpinan dan bias menjadi pemimpin. Dalam

\footnotetext{
15 Gien Karsen, Ia Dinamainya Perempuan (Bandung: Yayasan Kalam Hidup, 1977).61

16 Di sini Paulus menjelaskan bahwa tidak ada lagi pembedaan antara orang Yahudi dan Yunani, tidak ada lagi hamba atau orang merdeka, tidak ada lagi laki-laki atau perempuan, karena semuanya satu di dalam Kristus.

${ }^{17}$ Karsen, Ia Dinamainya Perempuan.61

18 Lagi pula di situ ada Hana, seorang nabi perempuan, anak Fanuel dari suku Asyer. Ia sudah sangat lanjut umurnya. Sesudah kawin ia hidup tujuh tahun lamanya bersama suaminya, dan sekarang ia janda dan berumur delapan puluh empat tahun. Ia tidak pernah meninggalkan bait Allah dan siang malam beribadah dengan berdoa dan berpuasa. Dan pada ketika itu juga datanglah ia ke situ dan mengucap syukur kepada Allah dan berbicra tentang Anak itu kepada semua orang yang menantikan kelepasan untuk Yerusalem, suatu tambahan penekanan.
} 
arah ini, Alkitab menjelaskan bahwa laki-laki dan perempuan mempunyai peranan masing-masing dalam dunia kepemimpinan.

\section{WANITA DALAM PELAYANAN GEREJA}

Ajaran Rasul Paulus tentang peranan perempuan dalam pelayanan gereja merupakan kelanjutan ajaran Yesus. Seperti diketahui, para penulis Alkitab tidak menuliskan kitabnya sesuka hati mereka, tetapi dengan pertolongan dan dorongan Roh Kudus sehingga tulisannya tidak mengandung kesalahan dan kekeliruan meskipun menceritakan kehidupan dan pelayanan mereka sendiri. Kitab mereka merupakan bagian firman Allah yang diilhamkan Allah (2 Timotius 3:16; 2 Petrus 1:20-21). Tulisan para Nabi dan Rasul adalah firman Allah yang dimiliki gereja sekarang dan merupakan pedoman satu-satunya dalam hidup, iman dan pelayanan.

Dalam Perjanjian Baru, Paulus memberikan petunjuk pelayanan yang harus diimplimentasikan dalam pelayanan gereja. Peranan perempuan dalam gereja secara khusus tidak luput dari perhatian. Ia memberikan regulasi yang mengatur pelayanan mereka. Meski demikian ia tidak pernah merendahkan pelayanan perempuan. Ia justru sangat menghargai pelayanan mereka dalam gereja dan pelayanannya (Roma 16), namun la menempatkannya sesuai dengan ketentuan dan kapasitas mereka sebagaimana diatur dalam firman Allah.

Sebelum lebih lanjut membahas tentang uraian perempuan dalam pelayanan gereja, maka terlebih dahulu perlu dipahami tentang dasar theologis filosofis kepemimpinan dalam gereja. Charles Swindoll dalam bukunya menjelaskan bahwa tidak mungkin untuk memimpin setiap orang tanpa menghadapi perlawanan (opoisi). Pemimpin harus belajar untuk menerima tekanan seperti itu. Dia akan menghadapi perlawanan - itu merupakan risiko dalam pekerjaan yang dilakukan setiap pemimin. ${ }^{19}$ Pemimpin Kristen harus memahami dasar kepemimpinan Kristen bahwa ia terpanggil sebagai pelayan-hamba (Markus 10:42-45) termasuk juga para kaum wanita, di mana mereka juga dipanggil untuk menjadi seorang pemimpin. Senada dengan hal tersebut, para pemimpin Kristen termasuk di dalamnya para wanita harus memiliki motif dasar kepemimpinan Kristen, yaitu membina hubungan dengan orang yang dipimpinnya/orang lain (Markus 3:13-1 (; Matius 10:1-4; Lukas 6:12-16) serta mengutamakan pengabdian yang menekankan bahwa kerja adalah fokus, prioritas, sikap utama serta tekanan utama.

\section{Wanita sebagai Nabiah}

Ada wanita lain dalam Perjanjian Baru yang Allah pakai dalam karunia nubuatan. Maria, ibu Yesus, tentu ada dalam kelompok ini (Lukas 1:46-55). Setiap kali kata-kata nubutan Maria dibacakan dalam ibadah gereja, dapat dikatakan bahwa seorang wanita sedang mengajar kepada jemaat. (Dan Allah pasti menghormati kedudukan wanita dengan mengirimkan Anak-Nya ke dalam dunia melalui seorang wanita, sesuatu yang mungkin telah la lakukan dengan cara-cara lain). Daftarnya berlanjut. Allah menubuatkan melalui nabi Yoel bahwa ketika Allah mencurahkan Roh-Nya, baik anak-anak laki-laki dan perempuan di Israel akan bernubuat (Yoel 2:28). Petrus menegaskan bahwa nubutan Yoel berlaku bagi

\footnotetext{
${ }^{19}$ Charles R. Swindoll, Hand Me Another Brick (NashVille: Thomas Nelson Inc, 1978).78
} 
ketentuan Perjanjian Baru (Kisah Para Rasul 2:17). Kisah Para Rasul 21:8-9 juga menjelaskan bahwa Filipus si penginjil mempunyai empat anak perempuan yang semuanya nabiah. Paulus menulis tentang para wanita yang bernubuat dalam perkumpulan jemaat (1 Korintus 11:5). Dari konteks itu, jelas ada pria-pria yang juga hadir. Dengan semua contoh Alkitab tentang para wanita yang dipakai Allah sebagai nabiah, dan menurut nubuatan, tentu tak punya alasan untuk tertutup kepada ide yang Allah dapat memakai wanita dalam pelayanan tersebut. Lagipula, tidak ada hal yang membawa seseorang untuk berpikir bahwa wanita tidak dapat bernubuat kepada pria demi nama Allah.

\section{Wanita sebagai Pendeta}

Jelas, jabatan pendeta atau penatua atau penilik dimaksudkan Allah untuk dipegang oleh pria: Benarlah perkataan ini: "Orang yang menghendaki jabatan penilik jemaat menginginkan pekerjaan yang indah." Karena itu penilik jemaat haruslah seorang yang tak bercacat, suami dari satu isteri, dapat menahan diri, bijaksana, sopan, suka memberi tumpangan, cakap mengajar orang, (1 Timotius 3:1-2, tambahkan penekanan). Aku telah meninggalkan engkau di Kreta dengan maksud ini, supaya engkau mengatur apa yang masih perlu diatur dan supaya engkau menetapkan penatuapenatua di setiap kota, seperti yang telah kupesankan kepadamu, yakni orang-orang yang tak bercacat, yang mempunyai hanya satu isteri. (Titus 1:5-6, tambahkan penekanan). Paulus tidak secara gamblang berkata bahwa wanita dilarang memegang jabatan, sehingga harus hati-hati membuat kesimpulan menyeluruh. Tampaknya, ada banyak wanita sebagai pendeta/penatua/penilik yang sangat efektif di seluruh dunia sekarang ini, terutama di negara-negara berkembang, namun jumlahnya masih sangat sedikit. Allah kadang-kadang memanggil wanita untuk peran pendeta/penatua/penilik ketika peran itu menjadi tujuan kerajaan-Nya yang bijak, atau ketika terjadi kekurangan pemimpin pria. Mungkin juga banyak pendeta wanita dalam tubuh Kristus kini sebenarnya dipanggil untuk jabatan lain dalam pelayanan yang Alkitabiah, seperti jabatan nabiah, tetapi struktur gereja kini hanya memungkinkan wanita untuk berperan sebagai pendeta. Mengapa jabatan pendeta/penatua/penilik diberikan kepada pria? Dengan memahami fungsi jabatan itu, maka hal itu membantu kita dalam pemahaman itu. Satu syarat menurut Alkitab untuk pendeta/penatua/penilik adalah, Seorang kepala keluarga yang baik, disegani dan dihormati oleh anak-anaknya. Jikalau seorang tidak tahu mengepalai keluarganya sendiri, bagaimanakah ia dapat mengurus Jemaat Allah ? (1 Timotius 3:4-5) Syarat itu sangat dapat diterima ketika kita sadar bahwa penatua dalam Perjanjian Baru mengawasi gereja rumah kecil. Perannya mirip dengan peran seorang bapak yang mengawasi rumah-tangganya. Hal itu membantu kita untuk memahami mengapa jabatan pendeta harus dipegang oleh pria, karena jabatan itu menggambarkan struktur keluarga yang, jika sesuai dengan rancangan Allah, harus dipimpin oleh seorang suami, bukan seorang istri.

\section{Wanita sebagai Rasul}

Dapat disimpulkan bahwa wanita dapat melayani dalam jabatan nabiah (jika dipanggil oleh Allah ). Bagaimana dengan jenis-jenis pelayanan lainnya? Dalam Roma 16, dapat dibaca kata-kata sapaan Paulus yang memuji beberapa wanita yang melayani demi Kerajaan Allah. Seseorang bahkan bisa saja disebut sebagai 
rasul. Dalam tiga kutipan berikut, ada beberapa nama wanita yang ditulis dalam huruf miring: Aku meminta perhatianmu terhadap Febe, saudari kita yang melayani jemaat di Kengkrea, supaya kamu menyambut dia dalam Tuhan, sebagaimana seharusnya bagi orang-orang kudus, dan berikanlah kepadanya bantuan bila diperlukannya. Sebab ia sendiri telah memberikan bantuan kepada banyak orang, juga kepadaku sendiri. (Roma 16:1-2). Ini merupakan dukungan yang mengagumkan. Tidak dijelaskan dengan rinci pelayanan apa yang dilakukan oleh Febe, tetapi Paulus menyebutnya "saudari kita yang melayani jemaat di Kengkrea" dan "telah memberikan bantuan kepada banyak orang", termasuk dirinya. Apapun yang dilakukannya untuk Tuhan pasti sangat bermanfaat, sehingga membuat Paulus mendukungnya untuk seluruh jemaat di Roma. Berikutnya, nama lain di anatara para wanita adalah tentang Priska (Priskila), yang, bersama dengan suaminya bernama Akwila, melakukan pelayanan sehingga mereka dihargai oleh seluruh jemaat yang bukan orang-orang Yahudi: Sampaikan salam kepada Priskila dan Akwila, teman-teman sekerjaku dalam Kristus Yesus. Mereka telah mempertaruhkan nyawanya untuk hidupku. Kepada mereka bukan aku saja yang berterima kasih, tetapi juga semua jemaat bukan Yahudi. Salam juga kepada jemaat di rumah mereka. Salam kepada Epenetus, saudara yang ku kasihi, yang adalah buah pertama dari daerah Asia untuk Kristus. Salam kepada Maria, yang telah bekerja keras untuk kamu. Salam kepada Andronikus dan Yunias [atau Junia, seperti diterjemahkan dalam Alkitab KJV, yang adalah seorang wanita], saudarasaudaraku sebangsa, yang pernah dipenjarakan bersama-sama dengan aku, yaitu orang-orang yang terpandang di antara para rasul dan yang telah menjadi Kristen sebelum aku. (Roma 16:3-7). Mengenai Yunias, wajarlah bila seseorang berpendapat bahwa yang "menonjol di antara para rasul" hanyalah seorang rasul. Jika, terjemahan yang benar adalah Junia, maka ia adalah rasul wanita. Priska dan Maria adalah pekerja bagi Tuhan. Salam kepada Ampliatus yang kukasihi dalam Tuhan. Salam kepada Urbanus, teman sekerja kami dalam Kristus, dan salam kepada Stakhis, yang kukasihi. Salam kepada Apeles, yang telah tahan uji dalam Kristus. Salam kepada mereka, yang termasuk isi rumah Aristobulus. Salam kepada Herodion, temanku sebangsa. Salam kepada mereka yang termasuk isi rumah Narkisus, yang ada dalam Tuhan. Salam kepada Trifena dan Trifosa, yang bekerja membanting tulang dalam pelayanan Tuhan. Salam kepada Persis, yang kukasihi, yang telah bekerja membanting tulang dalam pelayanan Tuhan. Salam kepada Rufus, orang pilihan dalam Tuhan, dan salam kepada ibunya, yang bagiku adalah juga ibu. Salam kepada Asinkritus, Flegon, Hermes, Patrobas, Hermas dan saudara-saudara yang bersama-sama dengan mereka. Salam kepada Filologus, dan Yulia, Nereus dan saudaranya perempuan, dan Olimpas, dan juga kepada segala orang kudus yang bersama-sama dengan mereka. (Roma 16:8-15). Dengan demikian, jelaslah bahwa wanita dapat menjadi "pekerja" dalam pelayanan.

\section{Wanita sebagai Guru}

Secara sekilas, mungkin kelihatan seperti Paulus membicarakan tentang karunia mengajar atau suatu kemampuan atau keterampilan dalam berkomunikasi. Namun tidak demikian, setidak-tidaknya bukan dengan cara kita menjelaskan 
metode-metode mengajar saat ini. Sebaliknya, soal mampu mengajar adalah kualitas hidup, sebuah aspek dalam karakter seseorang. ${ }^{20}$

Perjanjian Baru tidak menyebut seorangpun guru wanita. Tentu, Alkitab tidak juga menyebut guru pria. Priskila (seperti yang disebutkan di atas dan dikenal sebagai Priska), istri Akwila, ikut mengajar dalam skala kecil. Misalnya, ketika Priska dan Akwila mendengar Apolos mengabarkan Injil yang tidak lengkap di Efesus, "Mereka membawa dia ke rumah mereka dan dengan teliti menjelaskan kepadanya jalan Allah.” (Kisah Para Rasul 18:26). Tak seorangpun meragukan bahwa Priskila membantu suaminya mengajar Apollos, yang adalah seorang pria. Tambahan pula, dua kali dalam Alkitab, Paulus menyebutkan Priskila dan Akwila ketika ia menuliskan tentang "jemaat di rumah mereka" (Roma 16:3-5; 1 Korintus 16:19), dan ia menyebut mereka berdua "teman-teman sekerjaku dalam Kristus Yesus" dalam Roma 16:3. Ada keraguan bahwa Priskila berperan aktif dalam pelayanan bersama dengan suaminya. When Jesus commanded women to teach men. Sebelum memperhatikan kata-kata Paulus tentang wanita yang tetap diam di dalam jemaat dan ia melarang wanita untuk mengajar pria, perhatikan ayat lain dalam Alkitab yang memberi keseimbangan. Ketika Yesus dibangkitkan kembali, seorang malaikat menugaskan tiga wanita untuk mengajar murid-murid pria Yesus. Para wanita diajarkan untuk berkata kepada murid-murid itu bahwa Yesus telah bangkit dan la akan menampakkan diri kepada mereka di Galilea. Tidak hanya itu saja. Sejenak kemudian, Yesus Sendiri menampakkan diri kepada wanita-wanita itu dan memerintahkan mereka untuk mengajari murid-murid untuk pergi ke Galilea (Matius 28:1-10; Markus 16:1-7). Pertama, adalah penting jika Yesus memilih untuk menampakkan diri pertama kepada kelompok wanita dan kemudian pria. Kedua, jika, secara mendasar atau secara moral, ada sesuatu yang keliru dengan wanita yang mengajar pria, orang akan berpendapat bahwa Yesus tak mungkin berkata kepada wanita untuk mengajari pria tentang kebangkitan-Nya dan orang yang mungkin telah diberitahu oleh Dia sendiri (dan kelak ternyata memang terjadi). Pastilah, Tuhan Yesus menginstruksikan wanita untuk mengajar tentang kebenaran dan memberi pengajaran rohani kepada beberapa pria.

\section{KESIMPULAN}

Berdasarkan uraian di atas, jelaslah bahwa kepemimpinan itu bukanlah berbicara tentang gender yang selama ini menjadi topik permasalahan dalam dunia kepemimpinan. Kepemimpinan itu berbicara tentang fungsi dan peran dari masing-masing pemimpin. Peran serta fungsi tidak hanya didapat dari kaum lakilaki.

Ada satu unsur yang amat esensial dalam dunia kepemimpinan, itulah "pelayanan". Memimpin itu berarti melayani. Memimpin itu berarti mengabdi, menghamba. Tanpa unsur pelayanan ini, unsur-unsur kepemimpinan yang lain hanya memungkinkan orang menjadi seorang pemimpin yang terampil ( a skilled leader). Seorang pemimpin yang mampu (a capable leader). Tapi belum bisa memberinya kualifikasi sebagai seorang pemimpin yang sejati ( a true leader).

Pemimpin sejati harus memiliki sikap mental seorang pelayan. Harus memiliki motivasi seorang abdi. Harus bersikap dan bertindak seperti seorang hamba. la adalah pemimpin yang menghamba, sekaligus juga hamba yang memimpin.

\footnotetext{
${ }^{20}$ George Barna, Leaders on Leadership (Malang: Gandum Mas, 2002).112
} 
Dewasa ini kaum wanita telah menunjukkan perannya di berbagai sendi kehidupan. Tidak dapat dipungkiri lagi bahkan saat ini kaum wanita tidak boleh dipandang sebelah mata. Para pemimpin wanita telah menjamur, bukan hanya di dunia bisnis, di perpolitikan tapi juga telah merambah ke dalam gereja. Di dalam gereja pun peran serta fungsi wanita telah mewarnai segala bentuk pelayanan.

Penting untuk dipahami bahwa kriteria untuk memilih pemimpin-pemimpin dalam gereja bukanlah sekedar untuk pendeta, penatua atau diaken. Sebaliknya, apa yang diuraikan oleh Paulus dalam surat-suratnya kepada Timotius dan Titus merupakan ciri-ciri seorang pemimpin Kristen yang matang. Pada dasarnya Paulus menyatakan, "jika kamu ingin menjadi pemimpin rohani dalam gereja, itu baik sekali. Tetapi pastikan bahwa dirimu sudah matang!" entahkah itu pria atau wanita. Yang jelas bahwa orang-orang yang melayani sebagai pemimpin dalam gereja harus matang di dalam Kristus.

\section{Daftar Pustaka}

Barna, George. Leaders on Leadership. Malang: Gandum Mas, 2002.

Becher, Jeane. Perempuan, Agama Dan Seksualitas. Jakarta: BPK Gunung Mulia, 2004.

Elliston, Edgar J. Basic Leadership Defitnitions in the Introduction to Leadership Theory. Edited by Robert J Clinton. Pasadena: Fuller Theological Seminary, 1988.

Karsen, Gien. Ia Dinamainya Perempuan. Bandung: Yayasan Kalam Hidup, 1977.

Noehardi, Toety Heraty. Perempuan Indonesia. Jakarta: CV. Tomassu, 1991.

Oduyeye, Mercy. Siapa Yang Akan Menggulingkan Batu Itu? Jakarta: BPK Gunung Mulia, 1995.

Powers, Ward. The Ministry of Women in the Church. Australia: Southwood Press, 1996.

S, Pamudji. Kepemimpinan Pemerintahan Di Indonesia. Jakarta: PT. Bina Aksara, 1986.

Swindoll, Charles R. Hand Me Another Brick. NashVille: Thomas Nelson Inc, 1978.

Tomatala, Y. Kepemimpinan Yang Dinamis. Jakarta: YT. Leadership Foundation, 1998.

Tomatala, Yakob. Kepemimpinan Kristen. Jakarta: YT. Leadership Faundation, 2005. 